\title{
Evaluation of bitter apple (Citrullus colocynthis (L.) Schrad) as potential rootstock for watermelon
}

\author{
Mahdi Bigdelo ${ }^{1}$, Mohammad Reza Hassandokht ${ }^{1}$, Youssef Rouphael ${ }^{2}$, Giuseppe Colla ${ }^{3 *}$, Forouzandeh \\ Soltani $^{1}$, Reza Salehi ${ }^{1}$
}

\author{
${ }^{1}$ Department of Horticultural Sciences, Campus of Agriculture and Natural Resources, University of Tehran, \\ Karaj 31587, Iran \\ ${ }^{2}$ Department of Agricultural Sciences, University of Naples Federico II, 80055 Portici, Italy \\ ${ }^{3}$ Department of Agricultural and Forestry Sciences, University of Tuscia, 01100 Viterbo, Italy
}

*Corresponding author: giucolla@unitus.it (G. Colla)

\begin{abstract}
Selecting appropriate rootstocks in grafting is an important aspect to increase yield and fruit quality of vegetables. Interspecific hybrids and gourd are the most frequently used rootstocks for watermelon (Citrullus lanatus var. (Thunb.) Matsum. \& Nakai) grafting. However, other Citrullus species such as bitter apple (Citrullus colocynthis (L.) Schrad) have not been completely exploited and can be a source of interesting traits. The present study aimed to evaluate bitter apple as potential rootstock for watermelon (cv. Crimson Sweet) in comparison to the commercial rootstock Shintosa (Cucurbita maxima Duch. $\times$ Cucurbita moschata Duch.), and non-grafted plants. An experimental design of Randomized Complete Blocks was applied with treatments replicated three times. Grafted and non-grafted watermelon plants were compared in terms of yield, yield components, morphometric and textural characteristics, sweetness, acidity and mineral composition. The effect of Shintosa rootstock on total yield and mean fruit weight resulted in $20.2 \%$ and $14.0 \%$ increase over the non-grafted and Crimson Sweet/bitter apple combination, respectively. Flesh firmness and fruit mineral composition (Ca, P and $\mathrm{Zn}$ ) increased by grafting Crimson Sweet on Shintosa over the other grafting combinations. The most valued fruit quality traits for consumer satisfaction: fruit dry matter (DM) and total soluble solids (TSS) were significantly higher with bitter apple rootstock. The fruit DM and TSS contents recorded for Crimson Sweet grafted on bitter apple were significantly higher than those grafted on Shintosa by $11.7 \%$ and $8.4 \%$, respectively. Though grafting watermelon on bitter apple slightly decreased yield characteristics than Shintosa, on the other hand it improved flavor compounds with no serious detrimental effects on other quality attributes, thus it could be proposed as potential germplasm for watermelon rootstock breeding.
\end{abstract}

Keywords: Citrullus lanatus var. (Thunb.) Matsum. \& Nakai; grafting; mineral composition; rootstock-scion combination; soluble solids.

Abbreviations: Ca_calcium; DM_dry matter; EC_electrical conductivity; Fe_iron; Mg_magnesium; Mn_manganese; N_nitrogen; Na_sodium; P_phosphorus; K_potassium; SI_shape index; TSS_total soluble solids; Zn_zinc.

\section{Introduction}

Watermelon (Citrullus lanatus var. (Thunb.) Matsum. \& Nakai) is a field-grown vegetable crop widely cultivated in Asian countries, but it is also gaining popularity in other parts of the globe such as Brazil, Egypt and Uzbekistan (FAOSTAT, 2014). Iran is the third largest watermelon producing country after China and Turkey with 3.6 million tons per year (FAOSTAT, 2014). Vegetable farmers around the world only collect an average of $50 \%$ of the potential yield they would obtain under normal conditions, with a yield gap ranging between 60 to $70 \%$ in developing countries in Asia, Africa and Eastern Europe (FAO, 2014). Moreover, it is estimated that $65 \%$ of the yield gap is attributable to abiotic stresses, whereas $35 \%$ is associated to biotic factors (Peleg et al., 2011). Therefore, closing the yield gap represents a major challenge to the vegetable industry and scientists. In the last decades, vegetable breeders are making strenuous efforts to achieve cultivars with greater yield potential with good tolerance/resistance to a broad spectrum of biotic and abiotic factors (Louws et al., 2010; Schwarz et al., 2010). In spite of all these efforts, the commercial success of these cultivars has been hampered by the long period required for breeding programs as well as the genetically complex mechanisms conferring biotic and abiotic stresses tolerance. In order to overcome this situation, grafting elite vegetable cultivars on vigorous rootstocks has been suggested as a promising and effective tool to secure yield stability and reliability of Cucurbits and Solanaceous crops even under biotic and abiotic stress conditions (Lee et al., 2010). However, the grafting strategy leads to an extra cost for the growers due to the purchasing of grafted transplants, which are more expensive than non-grafted ones. Nevertheless, it is clear from the rapid increase in the industry take-up of grafting that the economic advantages (10-40\% increase in productivity) outweigh the extra costs (Colla et al., 2014). By selecting appropriate rootstocks, grafting can increase yield and fruit quality (Colla et al., 2008; Kyriacou et al., 2016; Miskovic et al., 2016), improve nutrient and water use efficiencies (Rouphael et al., 2008; 
Colla et al., 2010 a; 2011) and induce tolerance against biotic (Louws et al., 2010; Temperini et al., 2013) and abiotic stresses, among them salinity, adverse soil $\mathrm{pH}$, nutrient and heavy metals toxicity (Edelstein et al., 2005; Colla et al., 2010 b; 2012; 2013a; Borgognone et al., 2013; Rouphael et al., 2012; 2016; Kumar et al., 2015 a; b).

Even though the benefits of using grafted vegetable plants are now fully recognized, the need to enlighten the scientific basis of rootstock/scion interactions remains crucial for extracting grafting-mediated crop improvement (Colla et al., 2014). Thus, the identification of the most suitable rootstock/scion combinations is a basic requisite for the continued success of grafting.

Inter-specific hybrids $(C$. maxima Duchesne $\times C$. moschata Duchesne ex Poir) and gourd (Lagenaria siceraria L.) are the most frequently used rootstocks for watermelon grafting (Colla et al., 2006). There is a general consensus among scientists that grafting watermelons on appropriate rootstocks tends to improve fruit weight and productivity (Yetisir and Sari, 2003; Alan et al., 2007; Alexopolous et al., 2007; Cushman and Huan, 2008; Soteriou and Kyriacou, 2015). On the other hand, there are conflicting reports regarding effects of rootstocks on watermelon fruit quality, suggesting rootstock-cultivar specificity (López- Galarza et al., 2004;

Rouphael et al., 2010; Edelstein et al., 2014).

Most information on the impact of grafting on watermelon performance and quality is derived from studies using Cucurbita spp. or Lagenaria spp. as rootstocks. Nevertheless, limited data are available concerning the use of other potential wild genotypes/rootstocks able to increase marketable watermelon yield without negatively affecting the fruit quality. Citrullus colocynthis (L.) Schrad (Cucurbitaceae family), commonly known as bitter apple, is used as a medicinal plant in the pharmaceutical industry (Hussain et al., 2014). This plant is a drought-tolerant species with deep root system, widely distributed in the SaharaArabian region in Africa and the Mediterranean region (Dane et al., 2006). It can withstand harsh environments without wilting of the leaves or desiccation even under severe stress conditions (Nehdi et al., 2013). Therefore, the evaluation of bitter apple as a candidate watermelon rootstock could play an important role in vegetable industry, which is interested in selecting potential genotypes for producing high-quality vegetables.

In view of this background, the aim of the current study was to determine the effects of non-grafted and grafted watermelon using interspecific squash hybrid and bitter apple rootstocks on yield, yield components, and fruit morphometric and physiochemical attributes of diploid cultivar.

\section{Results and Discussion}

\section{Yield characteristics}

No differences in early yield occurred among the three grafting combinations. The Crimson Sweet/Shintosa had the greatest mean fruit weight, whereas an opposite trend was observed for the early fruit number with the highest values recorded in both non-grafted and Crimson Sweet/Bitter apple combination (Table 1). The effect of Shintosa rootstock on total yield resulted in $20.2 \%$ increase over the control (i.e., non-grafted) and Crimson Sweet/Bitter apple combination. Moreover, mean fruit weight was improved $(+14.0 \%)$ by grafting Crimson Sweet cultivar on the interspecific Cucurbita hybrid, whereas no differentiation in total fruit number was observed between the three grafting combinations (Table 1).

It is well established that vegetable grafting can promote plant yield in relation to several interacting processes including i) improvement of water and nutrient uptake resulting from the vigorous root system (Lee et al., 2010), ii) enhanced biosynthesis and production of endogenoushormones (Zijlstra et al., 1994) as well as iii) major tolerance to biotic and abiotic factors (Louws et al., 2010; Savvas et al., 2010; Schwarz et al., 2010). In the present study, increases in total yield in Crimson Sweet/Shintosa reflects plant vigor imparted by the $C$. maxima $\times C$. moschata rootstock rather than tolerance to biotic stresses in particular soil-borne and foliar pathogens because no deaths of non-grafted plants were observed. These results are consistent with the findings of Colla et al. (2006), Alan et al. (2007), Huitron et al. (2009), and Soteriou and Kyriacou (2015) who showed the positive effects of interspecific Cucurbita hybrid on diploid and triploid watermelon/mini-watermelon yield, assuming rootstock-scion compatibility (Yetisir and Sari, 2003). Our results also demonstrated that the highest total yield observed in Crimson Sweet/Shintosa was associated to an increase in fruit mean weight and not to a change in the number of fruit per plant. Fruit enlargement is the most prominent morphometric trait change delineated by grafting watermelon and mini-watermelon on Cucurbita rootstocks (Proietti et al., 2008, Edelstein et al., 2014, Soteriou and Kyriacou, 2015). A possible explanation of the fruit enlargement in Crimson Sweet watermelon grafted on the Cucurbita hybrid rootstock could be the increased uptake, translocation and accumulation of macro- and microelements $(\mathrm{Ca}, \mathrm{P}$ and $\mathrm{Zn})$, which may trigger photosynthesis (Colla et al., 2006; Rouphael et al., 2008).

\section{Fruit quality}

Neither the relative amounts of peel (avg. 39.6\%) pulp and seeds (avg. 60.4\%) nor the shape index (avg. 1.10) were affected by grafting combination (Table 2). The lack of difference in watermelon shape index could be expected since fruit shape constitutes a morphometric trait predominantly governed by scion genotype and little affected by environmental or cultural factors, including grafting (Colla et al., 2006; Alan et al., 2007; Proietti et al., 2008; Rouphael et al., 2008). Fruit-rind thickness increased significantly by $22.1 \%$ and $8.7 \%$ in fruits of Crimson Sweet grafted on Cucurbita hybrid and bitter apple compared to their non-grafted counterparts, with no significant difference observed between rootstocks (Table 2). The thickening of watermelon rind has been observed in previous reports on commercial interspecific Cucurbita hybrid and bottle gourd rootstocks (Alexopoulos et al., 2007; Proietti et al., 2008; Edelstein et al., 2014; Kyriacou and Soteriou, 2015). However, this has not been a ubiquitous effect with less known rootstocks such as $C$. moschata, Sicyos angulatus L., C. lanatus var. citroides and C. pepo (Alan et al., 2007; Davis et al., 2008; Huitrón et al., 2008). Moreover, flesh firmness one of the most important sensory traits of watermelon was significantly affected by grafting combination, with the highest values recorded on watermelon plants grafted on $C$. maxima $\times C$. moschata. These results confirm previous reports that interspecific Cucurbita hybrid tend to increase watermelon flesh firmness (Huitrón-Ramírez et al., 2009; Soteriou et al., 2014; Soteriou and Kyriacou, 2015). 
Table 1. Early yield and total yield of watermelon cv. Crimson Sweet non-grafted or grafted on Bitter apple and Shintosa rootstocks.

\begin{tabular}{|c|c|c|c|c|c|c|}
\hline \multirow[b]{2}{*}{ Grafting combination } & \multicolumn{3}{|c|}{ Early yield } & \multicolumn{3}{|c|}{ Total yield } \\
\hline & $\begin{array}{l}\text { Yield } \\
\text { (kg } \\
\text { plant })\end{array}$ & $\begin{array}{l}\text { Mean fruit } \\
\text { weight } \\
\left.\text { (kg fruit }^{-1}\right)\end{array}$ & $\begin{array}{c}\text { Fruit } \\
\text { number } \\
\left(\text { no. } \text { plant }^{-1}\right)\end{array}$ & $\begin{array}{c}\text { Yield } \\
\left(\text { kg plant }^{-1}\right)\end{array}$ & $\begin{array}{l}\text { Mean fruit } \\
\text { weight } \\
\left.\text { (kg fruit }^{-1}\right)\end{array}$ & $\begin{array}{c}\text { Fruit } \\
\text { number } \\
\left(\text { no. plant }{ }^{-1}\right)\end{array}$ \\
\hline Ungrafted Crimson Sweet & $7.04 \mathrm{a}$ & $6.82 \mathrm{~b}$ & $1.03 \mathrm{a}$ & $12.19 \mathrm{~b}$ & $7.10 \mathrm{~b}$ & $1.72 \mathrm{a}$ \\
\hline Crimson Sweet/Bitter apple & $7.21 \mathrm{a}$ & $6.74 \mathrm{~b}$ & $1.07 \mathrm{a}$ & $12.26 \mathrm{~b}$ & $7.21 \mathrm{~b}$ & $1.70 \mathrm{a}$ \\
\hline Crimson Sweet/Shintosa & $6.56 \mathrm{a}$ & $9.17 \mathrm{a}$ & $0.72 \mathrm{~b}$ & $14.70 \mathrm{a}$ & $8.16 \mathrm{a}$ & $1.80 \mathrm{a}$ \\
\hline Significance $^{\mathrm{a}}$ & ns & $*$ & $*$ & $* *$ & $* *$ & ns \\
\hline
\end{tabular}

${ }^{\mathrm{a}} \mathrm{ns},{ }^{*}, * *$ Nonsignificant or significant at $\mathrm{P} \leq 0.05$ and 0.01 , respectively. Different letters within each column indicate significant differences according to Duncan's multiple-range test $(\mathrm{P} \leq 0.05)$.
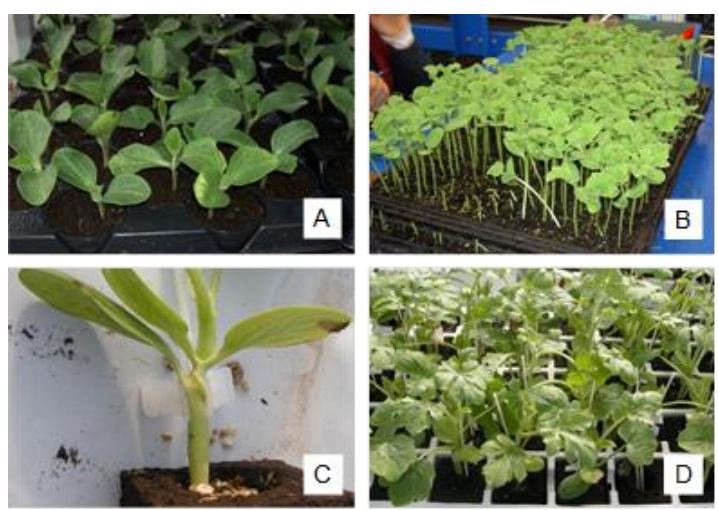

Fig 1. (A) Cucurbita rootstock, (B) watermelon scion, (C) splice graft with silicon clip, (D) grafted watermelon plants.

Table 2. Physical characteristics of fruits from watermelon cv. Crimson Sweet non-grafted or grafted on Bitter apple and Shintosa rootstocks.

\begin{tabular}{lccccc}
\hline Grafting combination & Peel $(\%)$ & $\begin{array}{c}\text { Pulp and seeds } \\
(\%)\end{array}$ & Shape index & Rind thickness (cm) & Flesh firmness (Nt) \\
\hline Ungrafted Crimson Sweet & $39.11 \mathrm{a}$ & $60.89 \mathrm{a}$ & $1.08 \mathrm{a}$ & $1.72 \mathrm{~b}$ & $2.20 \mathrm{~b}$ \\
Crimson Sweet/Bitter apple & $39.46 \mathrm{a}$ & $60.54 \mathrm{a}$ & $1.11 \mathrm{a}$ & $1.87 \mathrm{ab}$ & $2.22 \mathrm{~b}$ \\
Crimson Sweet/Shintosa & $40.21 \mathrm{a}$ & $59.79 \mathrm{a}$ & $1.10 \mathrm{a}$ & $2.10 \mathrm{a}$ & $2.39 \mathrm{a}$ \\
Significance $^{\mathrm{a}}$ & $\mathrm{ns}$ & $\mathrm{ns}$ & $\mathrm{ns}$ & $*$ & $* *$ \\
\hline
\end{tabular}

${ }^{a}$ ns, ${ }^{*}, * *$ Nonsignificant or significant at $\mathrm{P} \leq 0.05$ and 0.01 , respectively. Different letters within each column indicate significant differences according to Duncan's multiple-range test $(\mathrm{P} \leq 0.05)$.

Table 3. Dry matter content and chemical characteristics of fruit pulp from watermelon cv. Crimson Sweet non-grafted or grafted on Bitter apple and Shintosa rootstocks.

\begin{tabular}{lcccc}
\multicolumn{1}{c}{ Grafting combination } & Dry matter $(\%)$ & Electrical conductivity $\left(\mathrm{dS} \mathrm{m}{ }^{-1}\right)$ & $\mathrm{pH}$ & $\begin{array}{c}\text { Total soluble solids } \\
\left({ }^{\circ} \mathrm{brix}\right)\end{array}$ \\
\hline Ungrafted Crimson Sweet & $6.04 \mathrm{~b}$ & $2.53 \mathrm{ab}$ & $5.27 \mathrm{ab}$ & $9.33 \mathrm{ab}$ \\
Crimson Sweet/Bitter apple & $6.84 \mathrm{a}$ & $2.37 \mathrm{~b}$ & $5.43 \mathrm{a}$ & $9.55 \mathrm{a}$ \\
Crimson Sweet/Shintosa & $6.12 \mathrm{~b}$ & $2.76 \mathrm{a}$ & $5.11 \mathrm{~b}$ & $8.81 \mathrm{~b}$ \\
Significance $^{\mathrm{a}}$ & $* *$ & $*$ & $*$ & $*$ \\
\hline
\end{tabular}

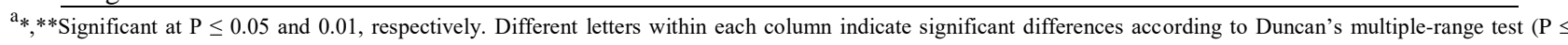
$0.05)$.

Table 4. Mineral composition of fruit pulp from watermelon cv. Crimson Sweet non-grafted or grafted onto Bitter apple and Shintosa rootstocks.

\begin{tabular}{|c|c|c|c|c|c|c|c|c|}
\hline \multirow[t]{2}{*}{ Grafting combination } & \multicolumn{4}{|c|}{$\begin{array}{l}\text { Macroelements } \\
\left(\mathrm{g} \mathrm{kg}^{-1} \mathrm{dw}\right)\end{array}$} & \multicolumn{4}{|c|}{$\begin{array}{l}\text { Microelements } \\
\left(\mathrm{mg} \mathrm{kg}^{-1} \mathrm{dw}\right)\end{array}$} \\
\hline & $\mathrm{K}$ & $\mathrm{Ca}$ & $\mathrm{Mg}$ & $\mathrm{P}$ & $\mathrm{Fe}$ & $\mathrm{Zn}$ & $\mathrm{Mn}$ & $\mathrm{Na}$ \\
\hline Ungrafted Crimson Sweet & $34.5 \mathrm{a}$ & $3.25 \mathrm{~b}$ & $4.30 \mathrm{a}$ & $2.21 \mathrm{~b}$ & $42.0 \mathrm{ab}$ & $12.2 \mathrm{~b}$ & $9.5 \mathrm{a}$ & $5.3 \mathrm{a}$ \\
\hline $\begin{array}{l}\text { Crimson } \quad \text { Sweet/Bitter } \\
\text { apple }\end{array}$ & $34.3 \mathrm{a}$ & $3.50 \mathrm{~b}$ & $2.75 \mathrm{~b}$ & $2.23 \mathrm{~b}$ & $33.5 \mathrm{~b}$ & $12.7 \mathrm{~b}$ & $8.0 \mathrm{a}$ & $5.2 \mathrm{a}$ \\
\hline Crimson Sweet/Shintosa & $35.2 \mathrm{a}$ & $4.25 \mathrm{a}$ & $3.00 \mathrm{ab}$ & $2.59 \mathrm{a}$ & $55.5 \mathrm{a}$ & $16.4 \mathrm{a}$ & $9.5 \mathrm{a}$ & $5.4 \mathrm{a}$ \\
\hline Significance $^{\mathrm{a}}$ & ns & $*$ & $*$ & $* *$ & $* *$ & $*$ & ns & $\mathrm{ns}$ \\
\hline
\end{tabular}


The juice electrical conductivity and $\mathrm{pH}$ were significantly affected by the grafting combination, with the lowest values recorded in Crimson Sweet/Bitter apple and Crimson Sweet/Shintosa, respectively (Table 3). The reduction of the $\mathrm{pH}$ of the pulp in Crimson Sweet/Shintosa has been observed earlier on mini-watermelon cv. Ingrid grafted on the commercial Cucurbita rootstock 'PS 1313' (Colla et al., 2006; Proietti et al., 2008). Finally, the most valued fruit quality traits for consumer satisfaction (fruit dry matter and total soluble solids) were also affected by grafting combination. In the scientific literature, the TSS of watermelon/mini-watermelon due to grafting is not highly compromised by grafting on most commercial interspesific Cucurbita rootstocks (Colla et al., 2006; Proietti et al., 2008; Rouphael et al., 2008; Kyriacou et al., 2016). This was the case in the current study since no improvement in TSS by grafting watermelon on Shintosa, when compared to the nongrafted control (Table 3). Interestingly, the fruit dry matter content and total soluble solids (TSS) contents recorded for Crimson Sweet grafted on bitter apple were significantly higher than those grafted on Shintosa by $11.7 \%$ and $8.4 \%$, respectively, whereas no significant difference was observed between Crimson Sweet/Bitter apple and the non-grafted plants (Table 3). There is general evidence that the use of bitter apple rootstock can deteriorate the fruit quality, in particular sweetness, and give a bitter taste due to the possible transfer of bitterness (e.g., cucurbitactins) from the rootstock to the scion. This was not the case in the present work, since the highest values of TSS were recorded in Crimson Sweet/Bitter apple combination. Moreover, sensory assessment carried out by a non-trained panel of laboratory personnel indicated that no bitterness was detected and concluded a pleasant organoleptic value from plants grafted on bitter apple rootstock. Our results are in agreement with those of Edelstein et al. (2014), who demonstrated that no cucurbitacins (e.g., bitter compounds) were detected in miniwatermelon fruits grafted on two bitter watermelon accessions.

\section{Mineral composition}

Fruits and vegetables significantly contribute toward human daily allowance of dietary vitamins and minerals required for maintaining a good health (Colonna et al., 2016). Levander (1990) reported that fruits and vegetables contribute normally by $11 \%, 35 \%, 7 \%$ and $24 \%$ to the human dietary intake of total $\mathrm{P}, \mathrm{K}, \mathrm{Ca}$ and $\mathrm{Mg}$, respectively. In the current experiment, the content of minerals in non-grafted and grafted watermelon fruit ranged as follows: $\mathrm{K}$ (34.3-35.2 $\mathrm{g}$ $\left.\mathrm{kg}^{-1} \mathrm{dw}\right), \mathrm{Ca}\left(3.25-4.25 \mathrm{~g} \mathrm{~kg}^{-1} \mathrm{dw}\right), \mathrm{Mg}\left(2.75-4.3 \mathrm{~g} \mathrm{~kg}^{-1} \mathrm{dw}\right)$, $\mathrm{P}$ (2.21-2.59 $\left.\mathrm{g} \mathrm{kg}^{-1} \mathrm{dw}\right), \mathrm{Fe}$ (33.5-55.5 $\left.\mathrm{mg} \mathrm{kg}^{-1} \mathrm{dw}\right), \mathrm{Zn}$ (12.2$\left.16.4 \mathrm{mg} \mathrm{kg}^{-1} \mathrm{dw}\right), \mathrm{Mn}\left(8.0-9.5 \mathrm{mg} \mathrm{kg}^{-1} \mathrm{dw}\right)$ and $\mathrm{Na}(5.2-5.4$ $\mathrm{mg} \mathrm{kg}^{-1} \mathrm{dw}$ ), with $\mathrm{K}$ and $\mathrm{Fe}$ being the most abundant macroand micronutrients (Table 4). No significant difference among grafting combinations was observed for $\mathrm{K}, \mathrm{Mn}$ and $\mathrm{Na}$ (avg. $34.6 \mathrm{~g} \mathrm{~kg}^{-1} \mathrm{dw}, 9.0$ and $5.3 \mathrm{mg} \mathrm{kg}^{-1} \mathrm{dw}$, respectively), whereas $\mathrm{Ca}, \mathrm{P}$ and $\mathrm{Zn}$ concentrations were significantly higher by $25.9 \%, 16.7 \%$ and $31.7 \%$, respectively in Crimson Sweet/Shintosa as compared with other grafting combinations (Table 4). The higher absorption of $\mathrm{Ca}, \mathrm{P}$, and $\mathrm{Zn}$ could be attributed to the higher rate of uptake of minerals from the soil by the vigorous roots of Shintosa rootstock and therefore improving the absorption of these macro- and micronutrients. Rouphael et al. (2008) and Salehi-Mohammadi et al. (2009) recorded similar results when mini-watermelon and Iranian melon cultivars were grafted on interspecific Cucurbita hybrid rootstocks and fruit mineral concentration increased.

\section{Materials and Methods}

Plant material, experimental design and crop management

The experiment was conducted in summer 2015 at the Experimental Farm of Tuscia University, central Italy (latitude $42^{\circ} 25^{\prime} \mathrm{N}$, longitude $12^{\circ} 08^{\prime} \mathrm{E}$, altitude $310 \mathrm{~m}$ ), on a sandy loam soil of volcanic origin (bulk density $1.1 \mathrm{~g} \mathrm{~cm}^{-3}$, $\mathrm{pH} 7.1$, organic matter $1.7 \%$, total $\mathrm{N} 0.1 \%$, available $\mathrm{P} 23 \mathrm{mg}$ $\mathrm{kg}^{-1}$, and exchangeable $\mathrm{K} 3155 \mathrm{mg} \mathrm{kg}^{-1}$ ).

Watermelon plants of the cultivar Crimson Sweet (Asgrow Vegetable Seeds, US) were used as the scion, whereas the commercial and widely used hybrids rootstock Shintosa (Cucurbita maxima Duch. × Cucurbita moschata Duch., Syngenta, Switzerland) and the Iranian wild accession of bitter apple (Citrullus colocynthis (L.) Schrad) were used as rootstocks. Fruits of the bitter apple were collected in fruiting stage during September 2014 from desert regions in central parts of Iran. Then, seeds were separated manually from the pulp of the plant and stored in a dry and cool place. Seeds of the hybrid Crimson Sweet (scion) and bitter apple (rootstock) were sown five days before the Cucurbita rootstock seeds to ensure uniformity in hypocotyls diameter of both the scion and rootstock. The 'splice graft' (Lee and Oda, 2003) was used for grafting the scion Crimson Sweet on the bitter apple and Shintosa rootstocks (Fig. 1). Grafted (Crimson Sweet/Bitter apple and Crimson Sweet/Shintosa) and nongrafted (Crimson Sweet) watermelon plants were transplanted on 16 May at a crop density of 5,000 plants ha ${ }^{-1}$. An experimental design of Randomized Complete Blocks was applied with treatments replicated three times. Each experimental unit consisted of twenty plants. Pre-plant fertilizer was broadcast $\left(\mathrm{kg} \mathrm{ha}{ }^{-1} ; 40 \mathrm{~N}-52 \mathrm{P}-75 \mathrm{~K}\right)$ and incorporated into the soil. Additional fertilizer $\left(\mathrm{kg} \mathrm{ha}^{-1} ; 80\right.$ $\mathrm{N}-75 \mathrm{~K}$ ) was applied four times through the drip system biweekly using $\mathrm{KNO}_{3}$ and $\mathrm{NH}_{4} \mathrm{NO}_{3}$ as sources of $\mathrm{N}$ and $\mathrm{K}$, respectively. Drip lines, with in-line emitters located $0.30 \mathrm{~m}$ apart and an emitter flow rate of $3.4 \mathrm{~L} \mathrm{~h}^{-1}$, were placed $10 \mathrm{~cm}$ away from the plants and were spaced with a 2-m distance between each lateral. All treatments were given uniform optimal irrigation (100\% irrigation level).

\section{Crop yield and yield components}

Fully mature fruits were harvested only twice on 27 July (i.e., early yield) and 5 August to evaluate the agronomic response of watermelon in a short cycle. Early and total marketable yield was determined on all plants coming from the experimental unit plot and expressed as kg plant ${ }^{-1}$. The fruit number per plant as well as the fruit mean weight were also recorded.

\section{Fruit quality measurements}

The watermelon fruits used for quality analysis were harvested 40 days post-fruit set, which correspond to the optimum harvest maturity in watermelon cultivars (Vinson et al., 2010). Immediately after harvest, ten fruits per experimental unit were tested for quality parameters. Fruit shape index defined as the ratio of equatorial land longitudinal lengths was measured. Peel thickness was measured at two points on each fruit cross section using an electronic caliper. Flesh fruit firmness $\left(\mathrm{N} \mathrm{cm}^{-2}\right)$ was 
determined by removing three discs of the skin surface in the equatorial area and using a penetrometer (Bertuzzi FT 011; Brugherio, Milan, Italy), fitted with an $8 \mathrm{~mm}$-diameter roundhead probe. The selected fruits were then cut into slices and separated into pulp, peel and seeds and the following fractions (peel and pulp + seeds) were weighed.

A homogenate prepared under low speed using a blender and filtered through double cheesecloth was obtained from the excised heart of each fruit. Part of it was used for determining the total soluble solids content at $20^{\circ} \mathrm{C}$ of the filtered juice on a digital refractometer (Atago N1, Atago Co. Ltd., Japan). The $\mathrm{pH}$ and electrical conductivity of the juice were measured with a pH-electrode (HI-9023; Hanna Instruments, Padova, Italy) and a conductivity meter (I991301; Hanna Instruments, Padova, Italy). The rest of the homogenate was dried in a forced-air oven at $80^{\circ} \mathrm{C}$ for $72 \mathrm{~h}$ and weighed to determine the fruit content dry matter.

\section{Mineral nutrient concentrations in fruit}

The dried fruit tissues were ground in a Wiley mill to pass through a 20 -mesh screen, then $0.5 \mathrm{~g}$ samples were analyzed for the following macro- and micronutrients: $\mathrm{P}, \mathrm{K}, \mathrm{Ca}, \mathrm{Mg}$, $\mathrm{Fe}, \mathrm{Mn}, \mathrm{Zn}$, and $\mathrm{Na}$ as described by Colla et al. (2013b). Briefly, $\mathrm{P}, \mathrm{K}, \mathrm{Ca}, \mathrm{Mg}, \mathrm{Fe}, \mathrm{Mn}, \mathrm{Zn}$, and $\mathrm{Na}$ were determined by dry ashing at $400^{\circ} \mathrm{C}$ for $24 \mathrm{~h}$, dissolving the ash in $\mathrm{HNO}_{3}$ $(1: 20 \mathrm{w} / \mathrm{v})$ and assaying the solution obtained using an inductively coupled plasma emission spectrophotometer (ICP Iris, Thermo Optek, Milan, Italy; (Karla 1998).

\section{Statistical analysis}

All experimental data were subjected to one way ANOVA using the SAS software (SAS 9.1 for Windows, 2012). Mean separation was performed using the Duncan's multiple range test at $p \leq 0.05$ on each of the significant variables measured.

\section{Conclusion}

Vegetable industry and growers have become more interested and demanding in enhancing vegetable field performance as well as fruit quality characteristics. Overall, grafting watermelon cultivar on interspecific Cucurbita hybrid enhances yield and yield components of the scion, improves flesh firmness and mineral composition $(\mathrm{Ca}, \mathrm{P}$ and $\mathrm{Zn}$ ) but tends to decrease some important quality parameters (e.g., total soluble solids). Interestingly, our data also demonstrated that grafting Crimson Sweet on bitter apple reduced slightly the total yield but improved the flavor compounds in particular dry matter content, soluble solids and acidity, and has no serious detrimental effects on other morphometric and textural characteristics. Therefore, this accession may be used as potential germplasm for watermelon rootstock breeding.

\section{Acknowledgement}

This work is part of Mahdi Bigdelo $\mathrm{PhD}$ thesis in Horticultural Sciences at University of Tehran, Iran. The University of Tehran is acknowledged for providing the fellowship to perform the trial at Tuscia University, Viterbo, Italy.

\section{References}

Alan O, Ozdemir N, Gunen Y (2007) Effect of grafting on watermelon plant growth, yield and quality. J Agron. 6: 362-365.
Alexopoulos AA, Kondylis A, Passam HC (2007) Fruit yield and quality of watermelon in relation to grafting. $\mathrm{J}$ Food Agric Environ. 5: 178-179.

Borgognone D, Colla G, Rouphael Y, Cardarelli M, Rea E, Schwarz D (2013) Effect of nitrogen form and nutrient solution $\mathrm{pH}$ on growth and mineral composition of selfgrafted and grafted tomatoes. Sci Hortic. 149: 61-69.

Colla G, Rouphael Y, Cardarelli M, Rea E (2006) Effect of salinity on yield, fruit quality, leaf gas exchange, and mineral composition of grafted watermelon plants. HortScience. 41: 622-627.

Colla G, Rouphael Y, Cardarelli M, Temperini O, Rea E, Salerno A (2008) Influence of grafting on yield and fruit quality of pepper (Capsicum annuum L.) grown under greenhouse conditions. Acta Hortic. 782: 359-363.

Colla G, Suãrez CMC, Cardarelli M., Rouphael Y (2010a) Improving nitrogen use efficiency in melon by grafting. HortScience. 45: 559-565.

Colla G, Rouphael Y, Cardarelli M, Salerno A, Rea E (2010b) The effectiveness of grafting to improve alkalinity tolerance in watermelon. Environ Exp Bot. 68: 283-291.

Colla G, Rouphael Y, Mirabelli C, Cardarelli M (2011) Nitrogen-use efficiency traits of mini-watermelon in response to grafting and nitrogen-fertilization doses. J Plant Nutr Soil Sci. 174: 933-941.

Colla G, Rouphael Y, Rea E, Cardarelli M (2012) Grafting cucumber plants enhance tolerance to sodium chloride and sulfate salinization. Sci Hortic. 135: 177-185.

Colla G, Rouphael Y, Jawad R, Kumar P, Rea E, Cardarelli $M$ (2013a) The effectiveness of grafting to improve $\mathrm{NaCl}$ and $\mathrm{CaCl}_{2}$ tolerance in cucumber. Sci Hortic. 164: 380391.

Colla G, Rouphael Y, Cardarelli M, Svecova E, Rea E, Lucini L (2013b) Effects of saline stress on mineral composition, phenolics acids and flavonoids in leaves of artichoke and cardoon genotypes grown in floating system. J Sci Food Agric. 93: 1119-1127.

Colla G, Fiorillo A, Cardarelli M, Rouphael Y (2014) Grafting to improve abiotic stress tolerance of fruit vegetables. Acta Hortic. 1041: 119-125.

Colonna E, Rouphael Y, Barbieri G, De Pascale S (2016) Nutritional quality of ten leafy vegetables harvested at two light intensities. Food Chem. 199: 702-710.

Cushman KE, Huan J (2008) Performance of four triploid watermelon cultivars grafted onto five rootstock genotypes: yield and fruit quality under commercial growing conditions. Acta Hortic. 782: 335-337.

Dane F, Liu J, Zhang C (2006) Phylogeograghy of the bitter apple, Citrullus colocynthis. Genet Resour Crop Evol. 54: 327-336.

Davis AR, Perkins-Veazie P, Sakata Y, Lopez-Galarza S, Maroto JV, Lee SG, Huh YC, Zhanyong S, Miguel A, King SR., Cohen R, Lee JM (2008) Cucurbit Grafting. Crit Rev Plant Sci. 27: 50-74.

Edelstein M, Ben-Hur M, Cohen R, Burger Y, Ravina I (2005) Boron and salinity effects on grafted and nongrafted melon plants. Plant Soil. 269: 273-284.

Edelstein M, Tyutyunik J, Fallik E, Meir A, Tadmor Y, Cohen R (2014) Horticultural evaluation of exotic watermelon germplasm as potential rootstocks. Sci Hortic. 165: 196-202.

FAO (2014) The State of Food and Agriculture http://www.fao.org/3/a-i4040e.pdf.

FAOSTAT (2014) Statistical database, www.faostat.org.

Huitron MV, Rodriguez N, Diaz M, Camacho F (2008) Effect of different rootstocks on the production and quality 
of watermelon cv. Reina de Corazones. Acta Hortic. 797: 437-442.

Huitron MV, Ricárdez M, Dianez F, Camacho F (2009) Influence of grafted watermelon plant density on yield and quality in soil infested with melon necrotic spot virus. HortScience. 44: 1838-1841.

Hussain AI, Rathore HA, Sattar MZA, Chatha SAS, Sarker SD, Gialni AH (2014) Citrullus colocynthis (L.) Schrad (bitter apple fruit): A review of its phytochemistry, pharmacology, traditional uses and nutritional potential. J Ethnopharmacol. 155: 54-66.

Karla YP (1998) Handbook of Reference Methods for Plant Analysis. CRC Press, Boca Raton, FL pp. 165-170.

Kumar P, Lucini L, Rouphael Y, Cardarelli M, Kalunke RM, Colla G (2015a) Insight into the role of grafting and arbuscular mycorrhiza on cadmium stress tolerance in tomato. Front Plant Sci. 6: 477.

Kumar P, Rouphael Y, Cardarelli M, Colla G (2015b) Effect of nickel and grafting combination on yield, fruit quality, antioxidative enzyme activities, lipid peroxidation, and mineral composition of tomato. J Plant Nutr Soil Sci. 178: 848-860.

Kyriacou MC, Soteriou GA, Rouphael Y, Siomos AS, Gerasopoulos D (2016) Configuration of watermelon fruit quality in response to rootstock-mediated harvest maturity and postharvest storage. J Sci Food Agric. 96: 2400-2409.

Lee JM, Oda M (2003) Grafting of herbaceous vegetable and ornamental crops. Hortic Rev. 28: 61-124.

Lee JM, Kubota C, Tsao SJ, Biel Z, Hoyos Echevaria P, Morra L, Oda L (2010) Current status of vegetable grafting: diffusion, grafting techniques, automation. Sci Hortic. 127: 93-105.

Levander OA (1990) Fruit and vegetable contributions to dietary mineral intake in human health and disease. HortScience. 25: 1486-1488.

López-Galarza S, San Batista A, Perez DM, Miquel A, Baixauli C, Pascual B, Maroto JV, Guardiola JL (2004) Effects of grafting and cytokinin - induced fruit setting on colour and sugar - content traits in glasshouse - grown triploid watermelon. J Hortic Sci Biotech. 79: 971-976.

Louws FJ, Rivard CL, Kubota C (2010) Grafting fruiting vegetables to manage soilborne pathogens, foliar pathogens, arthropods and weeds. Sci Hortic. 127: 127-146.

Miskovic A, Ilic O, Bacanovic J, Vujasinovic V, Kukic B (2016) Effect of eggplant rootstock on yield and quality parameters of grafted tomato. Acta Sci Pol-Hortoru. 15: 149-159.

Nehdi IA, Sbihi H, Tan CP, Al-Resayes SI (2013) Evaluation and characterization of Citrullus colocynthis (L.) Schrad seed oil: Comparison with Helianthus annuus (sunflower) seed oil. Food Chem. 136: 348-353.

Peleg Z, Reguera M, Tumimbang E, Walia H, Blumwald E (2011) Cytokinin-mediated source/sink modifications improve drought tolerance and increase grain yield in rice under water-stress. Plant Biotech J. 9: 747-758.

Proietti S, Rouphael Y, Colla G, Cardarelli M, De Agazio M, Zacchini M, Moscatello S, Battistelli A (2008) Fruit quality of mini-watermelon as affected by grafting and irrigation regimes. J Sci Food Agric. 88: 1107-1114.

Rouphael Y, Cardarelli M, Colla G, Rea E (2008) Yield, mineral composition, water relations, and water use efficiency of grafted mini-watermelon plants under deficit irrigation. HortScience. 43: 730-736.

Rouphael Y, Schwarz D, Krumbein A, Colla G (2010) Impact of grafting on product quality of fruit vegetables. Sci Hortic. 127: 172-179.
Rouphael Y, Cardarelli M, Rea E, Colla G (2012) Improving melon and cucumber photosynthetic activity, mineral composition, and growth performance under salinity stress by grafting onto Cucurbita hybrid rootstocks. Photosynthetica. 50:180-188.

Rouphael Y, Rea E, Cardarelli M, Bitterlich M, Schwarz D, Colla G (2016) Can adverse effects of acidity and aluminum toxicity be alleviated by appropriate rootstock selection in cucumber? Front Plant Sci. 7: 1283

Salehi-Mohammadi R, Khasi A, Lee SG, Huh YC, Lee JM, Delshad M (2009) Assessing survival and growth performance of Iranian melon to grafting onto Cucurbita rootstocks. Kor J Hortic Sci Technol. 27: 1-6.

Savvas D, Colla G, Rouphael Y, Schwarz D (2010) Amelioration of heavy metal and nutrient stress in fruit vegetables by grafting. Sci Hortic. 127: 156-161.

Schwarz D, Rouphael Y, Colla G, Venema JH (2010) Grafting as a tool to improve tolerance of vegetables to abiotic stresses: thermal stress, water stress and organic pollutants. Sci Hortic. 127: 162-171.

Soteriou GA, Kyriacou MC, Siomos AS, Gerasopoulos D (2014) Evolution of watermelon fruit physicochemical and phytochemical composition during ripening as affected by grafting. Food Chem. 165: 282-289.

Soteriou GA, Kyriacou MC (2015) Rootstock Mediated Effects on Watermelon Field Performance and Fruit Quality Characteristics. Int J Veg Sci. 21: 344-362.

Temperini O, Calabrese N, Temperini A, Rouphael Y, Tesi R, Lenzi A, Carito A, Colla G (2013) Grafting artichoke onto cardoon rootstocks: Graft compatibility, yield and Verticillium wilt incidence. Sci Hortic.149: 22-27.

Vinson EL, Woods FM, Kemble JM, Perkins-Veazie P, Davis A, Kessler JR (2010) Use of external indicators to predict maturity of mini-watermelon fruit. HortScience. 45: 1034-1037.

Yetisir H, Sari N (2003) Effect of different rootstock on plant growth, yield and quality of watermelon. Aust J Exp Agr. 43: $1269-1274$

Zijlstra S, Groot SPC, Jansen J (1994) Genotypic variation of rootstocks for growth and production in cucumber; possibilities for improving the root system by plant breeding. Sci Hortic. 56: 185-196. 